\title{
Evaluation of the potential for the use of lakes in restoring water resources and flood protection, with the example of the Noteć Zachodnia River catchment (Gniezno Lakeland, Poland)
}

\author{
Bogumił Nowak, Anna Nadolna \\ Institute of Meteorology and Water Management - National Research Institute, Podleśna 61, 01-673 Warsaw, Poland, \\ e-mail:rugosa@op.pl,anna.nadolna@imgw.pl \\ Paulina Stanek \\ Wroctaw University of Environmental and Life Sciences, The Faculty of Environmental Engineering and Geodesy, \\ Department of Mathematics, Grunwaldzka 53,50-357 Wrockaw, Poland, e-mail: paulina.stanek@upwr.edu.pl
}

\begin{abstract}
This paper presents the results of a study aimed at determining the possibility of water retention in the lakes located in the upper and middle reaches of the Noteć Zachodnia River in central-west Poland. The study was conducted on the basis of the analysis of available hydrological data and contemporary and archival topographic basemaps. The research was supplemented by a field study from the years 2011-2016, during which numerous surveys and hydrometric measurements were made. Their goal was to determine the natural range of water fluctuations in the lakes under consideration and to identify potential flows in the Noteć Zachodnia River.

Observations and calculations allowed the determination of damming ordinates that are within the range of natural water fluctuations of the lakes. On the basis of this information and the previously prepared model of terrain, including the test area, the authors designated zones within the lakes at the required water level and calculated the useful and flood capacity of those water reservoirs. Subsequently, the possibilities of reducing the flood wave on the Notec Zachodnia River were determined. Calculations were made for 2011, i.e. a year for which the highest winter spate for over 30 years has been documented. It has been shown that, by using only the flood capacities of surveyed lakes, it would be possible to reduce the flood wave on the Noteć Zachodnia River by $30 \%$ for the profile closing its catchment below Kamienieckie Lake.

The results indicated the validity of damming the lakes located in the catchment of the Noteć Zachodnia River. Water retention in these lakes would restore the water resources in the area and allow reduction of the flood wave during heavy rains. This action would positively affect the ecosystems associated with the river system and would assist the flood protection system in central and west Poland.
\end{abstract}

Keywords: Noteć Zachodnia River, dammed lakes, water resources, water retention, flood protection

Submitted 5 January 2018, revised 20 March 2018, accepted 27 April 2018

\section{Introduction}

Like most of the regions of Wielkopolska and Kujawy (central-west Poland), the catchment basin of the Noteć Zachodnia River (Fig. 1) is an area where a distinct trend towards a lowering of surface and ground water levels has been observed for decades (Graf 2010; Ilnicki et al. 2012a, b; Nowak, Przybyłek 2008; Przybyłek, Nowak 2011a; Sojka et al. 2017; Nowak 2018a). This is an effect of unfavourable climate changes (Kędziora 2008, 2011), deforestation, incorrect meliorations (Choiński, Ptak 2008; Kaniecki 2011; Marszelewski et al. 2011; Przybyłek, Nowak 2011a; Choiński et al. 2012; Nowak, Gezella-Nowak 2012; Ptak et al. 2013; Choiński et al. 2016; Nowak 2018a), excessive uptake of water for municipal and economic purposes, and mining drainage (Ilnicki 1996; Ilnicki, Orłowski 2006a, b; Orłowski, Ilnicki 2007; Przybyłek, Nowak 2011a, b). Some of the most visible effects of those transformations is the disappearance of wetlands and small water bodies (Choiński, Ptak 2008; Ilnicki et al. 2012a, b, 2017; Nowak 2018a), recession of the shoreline of lakes (Choiński, Ptak 2008; Marszelewski, Radomski 2008; Kunz et al. 2010; Ławniczak et al. 2011; Marszelewski et al. 2011; Ptak, Ławniczak 2011; Ilnicki et al. 2012a, b; Nowak, GezellaNowak 2012; Piasecki, Marszelewski 2013; Ptak 2013; Piasecki, Skowron 2014; Ławniczak, Kutyła 2015; Stachowski et al. 2016; Nowak 2018a), seasonal drying-up of smaller water courses (Przybyłek, Nowak 2011a; Nowak 2018a), and overgrowing of water reservoirs (Lawniczak 2010; Nowak et al. 2011a; Skowron, Jaworski 2017). All of those phenomena can be clearly observed in the catchment basin of the Noteć Zachodnia River. In the 


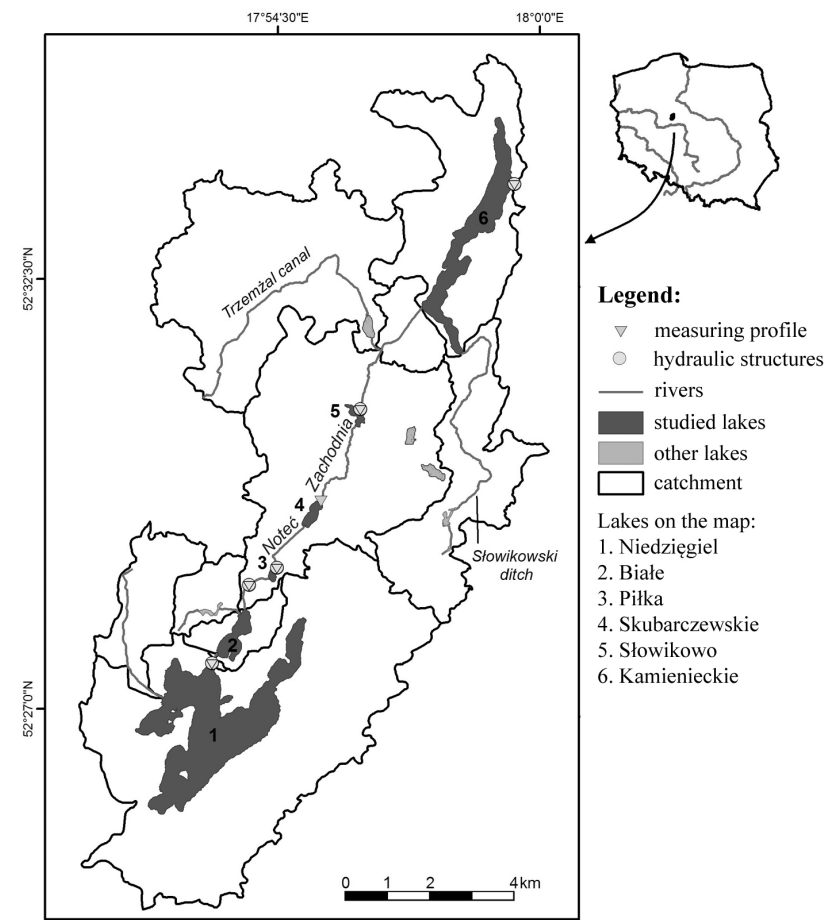

Fig. 1. Catchment basin of the river Noteć Zachodnia with tested objects

upper and central reaches, over the period of the last 30 years, the water body has changed from a river with a mean annual flow of over $0.2 \mathrm{~m}^{3} \cdot \mathrm{s}^{-1}$ to a periodic water course with water flow only in the spring (Fig. 2).

The loss of water is particularly observable in the lakes with which Noteć Zachodnia is directly associated. Over the period of half a century, their average water level decreased by over $0.5 \mathrm{~m}$. With the modest depths of these lakes, this has resulted in a reduction of their surface area and volume (for instance, Słowikowo Lake decreased its volume by more than 1/3) (Nowak 2018a, b). The uncovered littoral zones of those water bodies, which are habitats for many valuable species of aquatic plants and animals, transformed into willow and alder thickets. Such a drastic loss of water in the main drainage center of the entire catchment basin, including the riverbed and associated lakes, is also reflected in a lowering of the groundwater table in the glacial channel used by the hydrological objects described (Nowak 2018a, b). The effect of this is the disappearance of ponds associated with the river. Furthermore, in peats lining the valley, the process of their mucking began to be observed.

The main aim of the research was to evaluate the potential for restoring the lost water resources of the lakes in the Noteć Zachodnia River catchment through their damming. In addition, an attempt was undertaken to determine the effect of damming of the lakes on a reduction of flood waves that may potentially appear on the river under study.

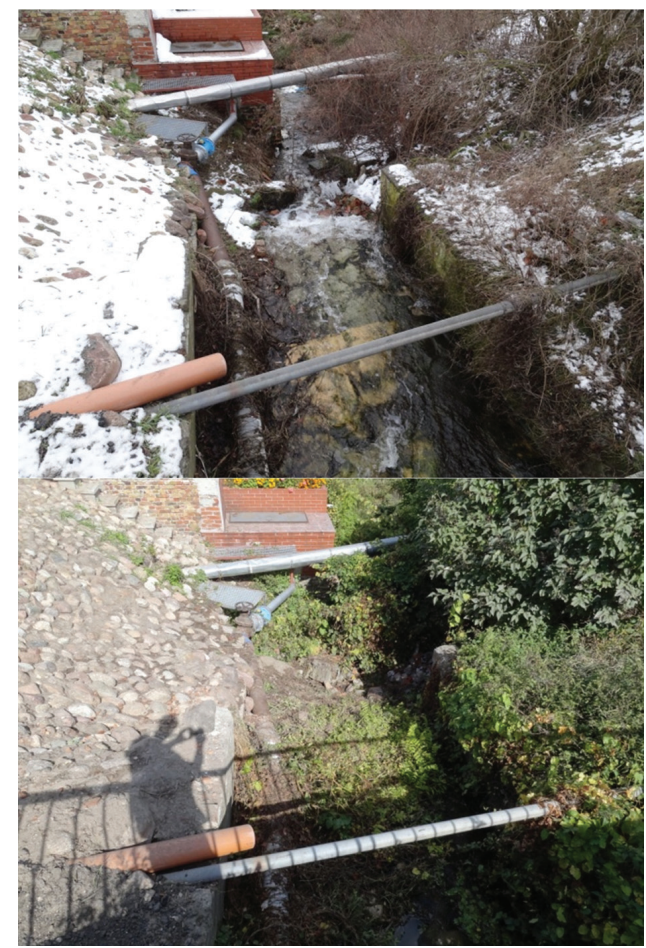

Fig. 2. Riverbed of Noteć Zachodnia in January (upper) and September (bottom) 2012

\section{Methods}

\subsection{Research material}

The first part of the study consisted of gathering, compiling and analyzing archival hydrological data and cartographic materials for the area of the studied catchment basin and its vicinity. The collected materials included, for example, maps and bathymetric charts of the explored lakes (Niedzięgiel Lake, Białe Lake, Skubarczewskie Lake, Słowikowo Lake, and Kamienieckie Lake) elaborated in the period of 1960-1995 by the Inland Fisheries Institute, Olsztyn, and the Institute of Meteorology and Water Management in Poznań. In the case of Lake Piłka, our own measurements were made using a Garmin GPS MAP 521S sonic depth finder. The measurements were made in 2015, and a bathymetric plan was made on their basis. For the cartographic analyses, the authors used orthophotomaps available in the service Geoportal.pl and maps from the last 100 years, in particular the Prussianj topographic maps at the scale of 1:25000 (so-called Messtischblatts), as well as historical and contemporary Polish topographic maps at the scales of 1:25000 (sheets: 364.43 Trzemeszno, 374.21 Witkowo) and 1:10000 (sheets: 364.432 Szydłowo, 364.434 Trzemżal, 374.212 Skubarczewo, 414.334 Słowikowo, 424.111 Ćwierdzin, 424.112 Słowikowo, 424.113 Witkowo, 424.114 Powidz, N-33-132-B-b-4 Wylatowo, N-33-132-B-d-2 Kamieniec, N-33-132-B-d-3 Słowikowo, N-33-132-B-d-4 Rękawczyn, N-33-132-D-a-2 Skorzęcin, N-33-132-D-b-1 Wylatkowo, 
N-33-132-D-a-4 Wiekowo, and N-33-132-D-b-3 Charbin). The hydrological and meteorological conditions of the study area were determined using data from the nearest existing and archival measuring stations of the Institute of Meteorology and Water Management National Research Institute.

\subsection{Field measurements}

The collected materials were used to create a database that constituted the input material for further work. Based on the collected information and field measurements, the water loss was determined for six lakes remaining in close hydraulic contact with the Noteć Zachodnia River.

Taking into account the information from topographic maps, available hydrological data and nature aspects, the range of natural variation of the water table in the studied water bodies was determined. Historical mean and high water levels were determined on the basis of the morphological edges and reaches of occurrence of several-dozen-year old trees related to the littoral zone of lakes, such as white willow (Salix alba) or black alder (Alnus glutinosa). Those parameters were determined by also taking into account information acquired from local inhabitants and users of the analyzed lakes, as well as data from contemporary topographic maps and bathymetric charts. Determination of the lowest historical water levels was made with the use of measurement data for lakes and rivers in the region of the Gniezno Lakeland, including Lake Niedzięgiel. On their basis, the potential periods of occurrence of the lowest water levels were determined. Next, following the information acquired from local inhabitants and the knowledge of one of the authors, who comes from the region, places were identified where the shorelines of the analyzed lakes receded during the lowwater periods of the beginning of the 1990s and of 2006 . Also helpful in this case were the natural premises and especially the reach of dead trees and bushes (approximately 12 years old) that inhabited the eulittoral zone in the period when it was devoid of water. Locations identified in this manner, both for high and low water levels, were related to a water level that was earlier related to the Kronstad '86 reference level. These operations were repeated for several locations on each of the lakes, and then mean values were determined. To test the credibility of the applied method, the obtained results were compared with historical data for Lake Niedzięgiel and several other lakes from the area of the Gniezno Lakeland for which measurement data has existed since at least the mid-1950s. It was demonstrated that the ordinates calculated on the basis of field measurements did not differ from data recorded on water gauges by more than $10 \mathrm{~cm}$. Having that knowledge, and taking into account the geomorphological conditions and existing hydrotechnical infrastructure, damming ordinates were determined for the selected lakes.

The next part included field studies in which geodetic surveys were conducted for the lakes and the main water courses of the catchment of the Notec Zachodnia River. These studies were aimed at determining the archival and contemporary ordinates of surface water tables in the study area. The measurements were related to the national network of elevation benchmarks at reference level Kronstad '86. Water gauges were installed at selected locations, at which control readouts of water levels were taken to determine the range of seasonal variations. Hydrometric measurements were also made at designated measurements profiles, conducted in conformance with the method used in the National Hydrological-Meteorological Service. In the field surveys, inventory was taken of the existing hydrotechnical devices and structures within the study area. Each of those objects was measured and levelled, relating to the reference level Kronstad '86. The collected data on the hydrotechnical objects situated in the course of the Noteć Zachodnia River were compared with information from the Wielkopolski Board of Melioration and Hydrotechnical Structures in Poznań. This allowed the verification of the technical parameters of those structures determined previously. In the course of the field surveys, the local inhabitants were interviewed to verify the information acquired earlier.

\subsection{Determination of characteristic levels and damming ordinates of the lakes}

The range of natural oscillations of water levels in the analyzed water bodies was determined by taking into account the information from the topographic maps, the available hydrological data, and nature aspects. The historic mean levels $\left(\mathrm{SSW}_{60}\right)$ and high water levels $\left(\mathrm{SWW}_{60}\right)$ were determined on the basis of the morphological edges and the reaches of occurrence of several-dozen-year old trees associated with the littoral zones of the lakes, such as white willow (Salix alba) or black alder (Alnus glutinosa). When determining those parameters, the authors also took into account the information acquired from local inhabitants and the users of the analyzed lakes, as well data from contemporary topographic maps and bathymetric charts. The historically lowest water levels were determined by using the available measurement data from lakes and rivers in the region of the Gniezno Lakeland, including Lake Niedzięgiel. Those data served to determine the potential periods of occurrence of the lowest water levels. 
Next, places were determined in the analyzed lakes where the shoreline receded during the lows of the beginning of the 1990s and in the year 2006 based on information acquired from the local inhabitants and on the knowledge of one of the authors, who happens to come from the region. In this case, the nature aspects also proved to be of use, especially the reach of dead trees and bushes over ten years old that inhabited the eulittoral zone in the period when it was devoid of water. Locations indicated in this manner, both for high and low water levels, were referenced to the reference level Kronstad '86. The procedure was repeated for several locations on each of the lakes, and then the mean values were calculated. To validate the method applied, the results obtained were compared with historical hydrological data from Lake Niedzięgiel and several other lakes in the area of Gniezno Lakeland, for which measurement data has existed since at least mid1950s. It was demonstrated that the ordinates calculated on the basis of the field measurements did not differ from the data recorded on the water gauges by more than $10 \mathrm{~cm}$. Based on that knowledge, and taking into account the geomorphological conditions and the existing hydrotechnical infrastructure, damming ordinates were determined for the selected lakes.

\subsection{Determination of the capacity of the lakes and of the flow in the river}

For further calculations and analyses, it was necessary to create a digital model of the relief of the study area, taking into account the morphometry of the lake basins. For that purpose the authors used the digital terrain model (DTM) made available by the Geodetic and Cartographic Documentation Centre, with $1 \times 1 \mathrm{~m}$ resolution and a mean elevation error $<0.2 \mathrm{~m}$. The above DTM was enhanced in terms of its detail on the basis of a topographic map with 1:10000 scale and available bathymetric maps of the lakes. This required that all of the basemaps be reduced to the same coordinate system in this case PUWG 1992. The shorelines of the lakes were digitalized from the topographic maps. The bathymetric maps of the studied water bodies, vectorized previously (registered in the PUWG 1992 system), were composed into their shapes using the flexible fit function (rubbersheet). That function performs local conversions by means of superimposed control points, enabling the user to impart any location to the analyzed section of the object under study (Urbański 2008). The vectorized isobaths were given depth values, expressed as absolute elevations (in conformance with the Kronstadt ' 86 reference system). The isohypses situated in the closest vicinity of the water bodies were also digitized, which allowed the determination of the extent of the lakes at ordinates higher than those noted on the topographic maps. Using the digitalized isobaths, lake shorelines and isohypses as input data, digital models of the lake basins were created in the program ArcGIS (Topo to Raster function), with $1 \mathrm{~m}$ resolution, and then combined with the DTM (Mosaic function). The next step of the geographic information analyses was the calculation of the surface areas and volumes of the lakes at various water level ordinates, using the Cut/fill tool.

On the basis of the digital terrain model of the study area, the reach zones of dammed lakes were determined for an adopted ordinate. This allowed the estimation of the utility and flood capacities of the selected lakes, as well as the determination of the effect of the achieved retention capacities of the lakes on the passage of the flood wave that took place on the Noteć Zachodnia River in the winter of 2011. Using the developed model of terrain, calculations were also made of the capacity of the lakes at characteristic water levels from the 1960s and from recent times. By juxtaposing those values, the water loss that took place in each of the analyzed lakes over the last 50 years was calculated.

The calculations were made with the use of data from the nearest water gauge station situated on the Noteć Zachodnia River in Gębice, as well as control measurements of flow conducted in the period of 2011-2015 in the upper and central sections of the river (Nowak 2018a).

The method of hydrological analogy (Wokroj 1967; Cupak 2012) was used to determine the flow intensity in the selected measurement profiles on the Noteć Zachodnia. The calculations were conducted using data from the nearest IMWM-NRI gauge station, situated on the Noteć Zachodnia in Gębice, as well as from control measurements of flow made in the upper and middle sections of the river from 2011 to 2016 (Nowak 2018a, b). The calculations were made for the years 2011-2015. The choice of that period was based on the availability of data and the reference character of the study period. In that period, the highest winter spate for over 30 years and one of the most dramatic hydrological lows in history were documented (Fig. 3-5).

\subsection{Statistical methods}

In the estimation of trends of selected data series, linear regression was applied based on the least squares method (Linear Least Squares Regression). Next, the significance of the slope index of the regression line was determined. This was done using the function $l m$ in the R program. First, the annual precipitation totals measured at the pre- 


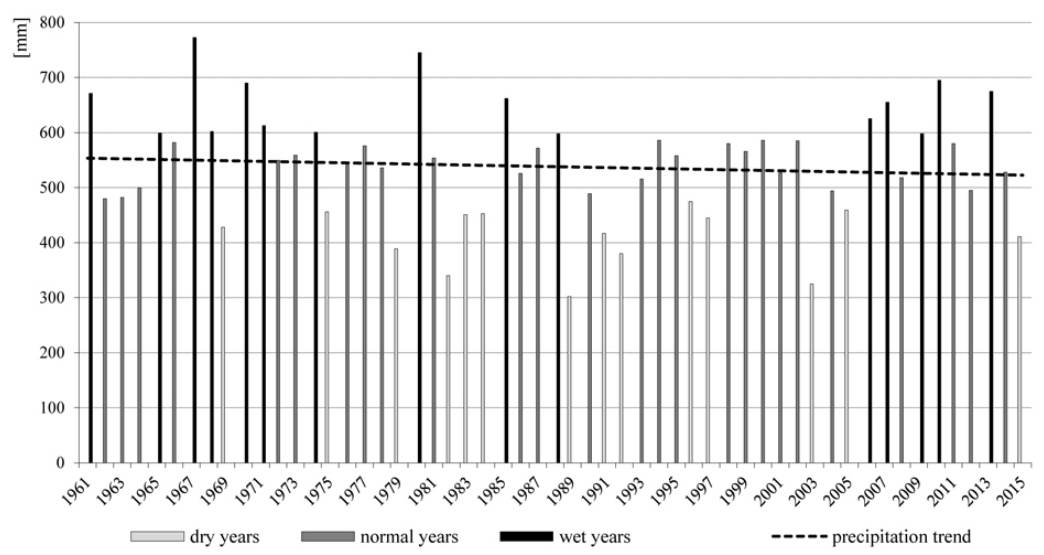

Fig. 3. Annual precipitation totals measured at the precipitation station at Powidz for 1961-2015 (based on IMWM-NRI data); regression line: $y=-0.57 x+1676$ - decreasing trend, statistically insignificant $(R=0.091, p$-value $\sim 0.5)$

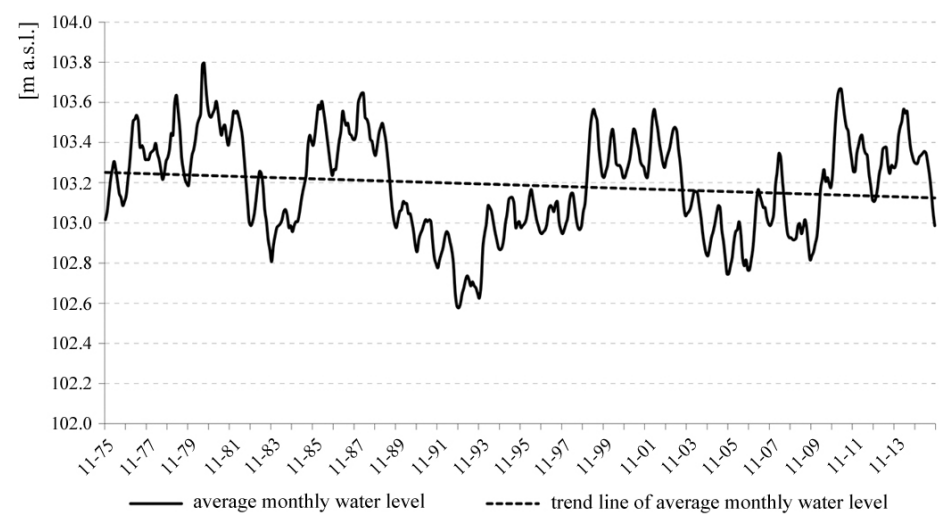

Fig. 4. Mean monthly water levels of Lake Niedzięgiel at water gauge profile Skorzęcin in 1976-2015 (on the basis of IMWM-NRI data); regression line: $y=-8.8^{*} 10^{\wedge}(-6) x+103.27$ - decreasing trend, statistically significant $(R=0.152, \alpha=0.001)$

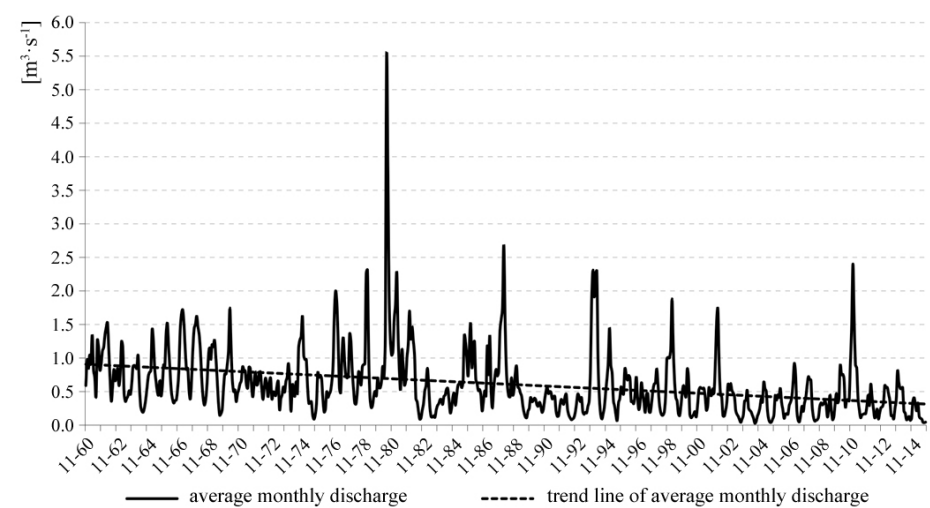

Fig. 5. Mean monthly flows in profile Gębice on Noteć Zachodnia in 1961-2015 (on the basis of IMWM-NRI data); regression line: $y=-2.959^{*} 10^{\wedge}(-5) x+0.81-$ decreasing trend, statistically significant $(R=0.346, \alpha=0.001)$

cipitation station in Powidz in the period 1961-2015 were analyzed (Tab. 1, Fig. 2). The calculated regression line was $y=-0.57 x+1676$. After testing the null hypothesis (slope index $=0$ ), it was decided that there are no grounds for the rejection of the null hypothesis at the significance level of 0.05 . The trend was found to be statistically insignificant. It should be added that the coefficient of correlation was only $R=0.091$. In addition, the five-year precipitation totals for the stations Trzemeszno, Gębice, Strzelno, and Kołuda Wielka were analyzed. At each of the stations, the trend calculated by means of linear regression proved to be statistically insignificant (at the significance level of $\alpha=0.05$ ). An analogous method was used to analyze hydrological data, such as the following:

- the lowest, highest and average monthly water levels of Lake Niedzięgiel at the water gauge profile Skorzęcin in the years 1976-2015 (Fig. 3);

- the lowest, highest and average monthly flows at the profile Gębice on the Noteć Zachodnia in the years 1961-2015 (Fig. 4);

- the lowest, highest and average monthly water levels and the average monthly water flows of the Noteć 
Table 1. Annual precipitation totals at selected precipitation stations in the study region in successive five-year periods of the multi-year period of 1961-2015 (based on IMWM-NRI data)

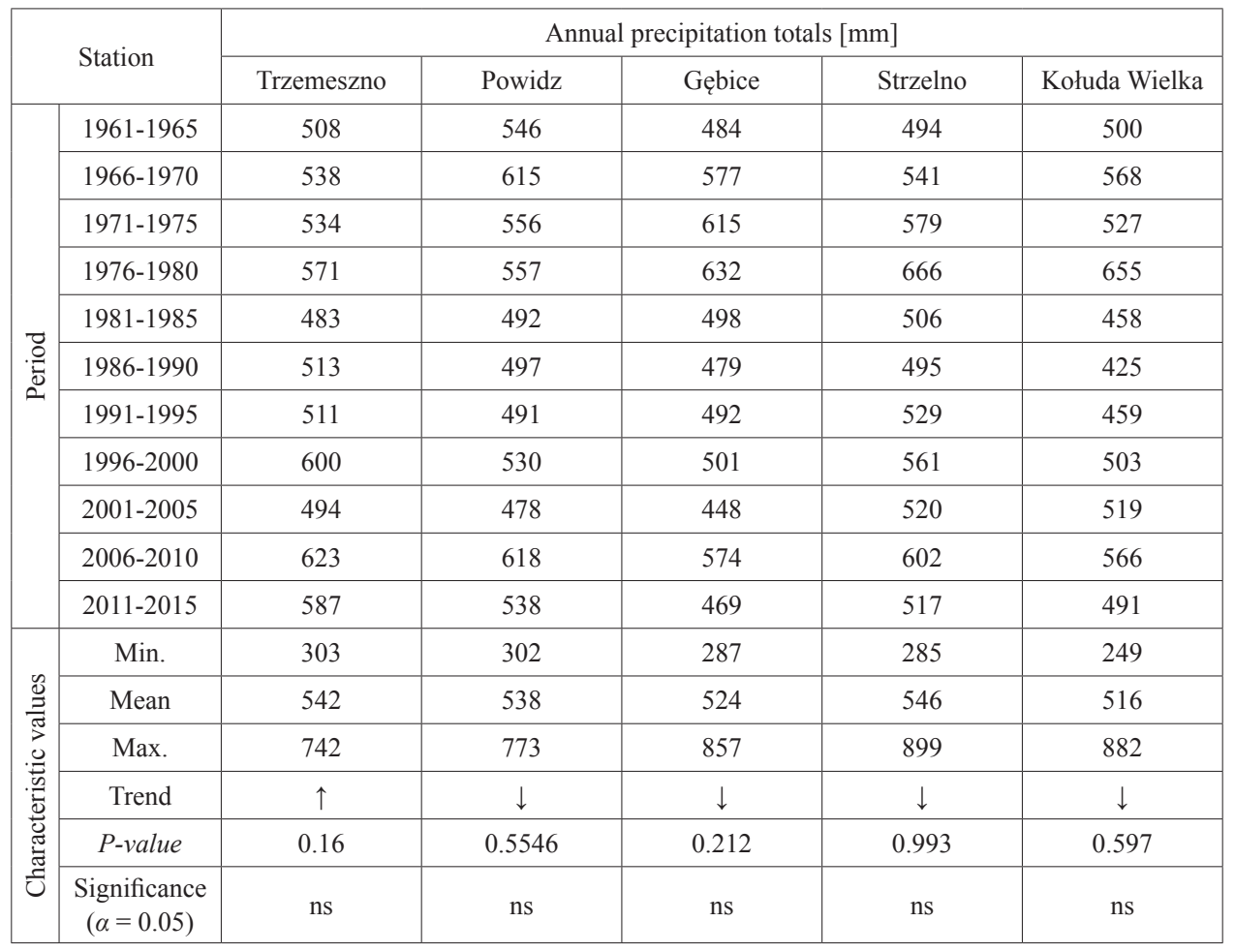

Min. - lowest precipitation total in multi-year period; Mean - mean for multi-year period; Max highest precipitation total in multi-year period, $\uparrow$ - positive trend $\downarrow$ - negative trend, $P$-value - for regression line, ns - non-significant

Zachodnia at the profile Słowikowo in the years 20112015 (Fig. 5).

After testing the null hypotheses (regression line slope index $=0$ ), they were rejected at the significance level of $\alpha=0.01$. For the above data, all of the trends were found to be decreasing and statistically significant.

\section{Study area}

The study area is the catchment basin of the upper and middle Noteć Zachodnia River, which is one of the main rivers of the Gniezno Lakeland situated in central-west Poland (Fig. 1). Its length is $47.56 \mathrm{~km}$, and the area of its catchment basin is $720.72 \mathrm{~km}^{2}$. Its origin is in the northern edge of Lake Niedzięgiel, and from there it flows northwards (Fig. 1) using the terrain depression delineated by the sub-glacial Skorzęcińsko-Pakoska channel stretching along a meridian direction. Along its route, it passes through numerous water reservoirs that differ both genetically and in terms of their trophy. Beginning from the sources of the river, the lakes include Białe, Piłka, Skubarczewskie, Słowikowo, Kamienieckie and Bronisławskie (Fig. 1). In the wider parts of the valley of Notec Zachodnia, especially in its upper section, there are numerous ponds, some of which are used for fish breeding. The river ends its run at Lake Pakoskie, where it joins the Noteć River. Its catchment basin has an agricultural-forest character in the south part, and it has a typically agricultural land (arable land and partly grassland) in the central and northern parts. The landscape is dominated by sandy-loamy frontal moraine hills dissected by a network of glacial channels and river valleys. The substrate is dominated by loams and ablation sands in the south part of the catchment basin, and boulder loams in the central and north parts (Nowak 2018).

Against the background of the climate conditions of Poland, the area under discussion is characterized by one of the lowest sums of annual precipitation $\left(<550 \mathrm{~mm} \cdot\right.$ year $^{-1}-$ on the basis of data of the Institute of Meteorology and Water Management - National Research Institute (IMWM-NRI)) and a high potential evaporation, amounting to an average of over $600 \mathrm{~mm} \cdot$ year $^{-1}$ (Kędziora 2008; Przybyłek, Nowak 2011a; Ilnicki et al. 2012a, b). Maximum deviations of annual precipitation totals in a wet year compared with a normal year for a multi-year period are $140-160 \%$, and they are $50-60 \%$ in a dry year. Converted to numerical values, this corresponds to precipitation totals of $700-800 \mathrm{~mm} \cdot$ year $^{-1}$ in wet years and less than $400 \mathrm{~mm} \cdot$ year $^{-1}$ in dry years (Fig. 3). Taking into account precipitation data from neighboring stations (Tab. 1), one can note that over the period of 1961-2015 
in the study area, the precipitation data show a slight decreasing tendency (although the results for the individual measurement points may differ from one another). Those trends, however, are not statistically significant.

Apart from the differences in precipitation amounts in individual years at each of the stations taken into account in the study, one can also observe a tendency in their spatial variation. Precipitation totals are the highest in the northwestern part of the study area and decrease in the eastern and southern directions (Nowak 2018a). Taking into account the lithological structure of the catchment basin and its use, it has a significant bearing on the potential surface and underground supply of lakes and water courses in its particular sections. Similar to precipitation, evaporation from open water surfaces is subject to significant fluctuations. However, over the last several decades, there is a distinct tendency towards an increase in evaporation from open water surfaces in that area. This is particularly observable since the end of the $20^{\text {th }}$ century, when there were many times when evaporation totals exceeded $700 \mathrm{~mm} \cdot$ year $^{-1}$, attaining levels above $800 \mathrm{~mm} \cdot$ year $^{-1}$ in extreme cases (Kędziora 2008, 2011; Przybyłek, Nowak 2011a; Stachowski et al. 2016; Nowak 2018a).

Those unfavorable climate conditions are reflected in the hydrological conditions of the study area. Against the background of Poland, that area, as well as neighboring catchment basins situated to the east, are characterized by very low mean unit outflows that do not exceed $2 \mathrm{l} \cdot \mathrm{s}^{-1} \cdot \mathrm{km}^{-2}$ (Przybyłek, Nowak 2011a; Nowak 2018a) (it should be added here that, in particular years and parts of the catchment basin, it can vary in the range from 0 to over $101 \cdot \mathrm{s}^{-1} \cdot \mathrm{km}^{-2}$ ).

In this area, high values of evaporation combined with low annual precipitation totals are the cause of the appearance of water deficits that are the highest in Poland (Kędziora 2008; Nowak 2011a; Przybyłek, Nowak 2011a). Water deficit, which is reported as the difference between the annual precipitation and the annual value of potential evaporation (i.e. from the open water surface), reaches as high as $200 \mathrm{~mm}$. Similarly to those situated nearby, the catchment basin under discussion is thus distinctly susceptible to water deficits, and hydrological and hydrogeological lows are observed here with particular clarity (Przybyłek, Nowak 2011a; Ilnicki et al. 2012a, b; Stachowski et al. 2016; Nowak 2018a). In turn, those are most visible on the lakes whose water levels have decreased notably in recent decades due to the low potential for restoration of water resources (Ilnicki, Orłowski 2006a, b; Orłowski, Ilnicki 2007; Marszelewski, Radomski 2008; Marszelewski et al. 2011; Przybyłek, Nowak 2011a, b; Ilnicki et al. 2012a, b; Nowak, Gezella-Nowak 2012; Piasecki, Marszelewski 2013; Stachowski et al. 2016; Nowak 2018a) (Tab. 2, Fig. 4).

On the other hand, according to the flows of the Noteć Zachodnia recorded on the water gauge at Gębice (Fig. 5) and the flows in the profile Słowikowo (Fig. 6), the river can rise violently as a result of torrential rains or thaws. This leads to flooding of the lowest situated parts of the river valley and restoration of the water resources of lakes situated in the catchment basin of Noteć Zachodnia (Fig. 4 and 7). Such situations, however, are very rare in recent years. As a result, a constant loss of both surface and ground waters is observed here (Ilnicki, Orłowski 2006a, b; Orłowski, Ilnicki 2007; Marszelewski, Radomski 2008; Marszelewski et al. 2011; Przybyłek, Nowak 2011a, b; Ilnicki et al. 2012a, b; Nowak, Gezella-Nowak 2012; Piasecki, Marszelewski 2013; Stachowski et al. 2016; Nowak 2018a).

\section{Results}

The study demonstrated that a lowering of the level of explored lakes in the catchment basin under study has been taking place since at least the beginning of the $20^{\text {th }}$ century. The table of water levels in selected lakes situated in the catchment basin of the Noteć Zachodnia River

Table 2. Changes of water levels of lakes in the study region over the last 100 years

\begin{tabular}{|l|c|c|c|c|c|c|c|}
\hline Lake\Year & 1911 & 1936 & 1960 & 1980 & 1995 & 2001 & 2010 \\
\hline Niedzięgiel (Skorzęcińskie) & $103.9^{1}$ & $103.9^{1}$ & $103.5^{2}$ & $103.7^{3}$ & $103.2^{3}$ & $103.5^{3}$ & $103,3^{3}$ \\
\hline Białe & $103.9^{1}$ & $103.9^{1}$ & $103.5^{2}$ & $103.4^{1}$ & $103.2^{1}$ & $103.4^{1}$ & $103.3^{4}$ \\
\hline Piłka & $97.9^{1}$ & $97.9^{1}$ & b.d. & b.d. & b.d. & $101.5^{1}$ & $101,3^{4}$ \\
\hline Skubarczewskie & $93.0^{1}$ & $93.0^{1}$ & $92.7^{1}$ & $92.6^{1}$ & $91.7^{1}$ & $92.1^{1}$ & $91,6^{4}$ \\
\hline Słowikowo & $92.9^{1}$ & $92.9^{1}$ & $92.9^{1}$ & $93.0^{1}$ & $91.4^{1}$ & $92.0^{1}$ & $91,6^{4}$ \\
\hline Kamienieckie & $85.5^{1}$ & $85.5^{1}$ & $85.6^{2}$ & $84.5^{1}$ & $84.3^{1}$ & $84.5^{1}$ & $84,3^{4}$ \\
\hline
\end{tabular}

${ }^{1}$ Ordinates determined on the basis of topographic maps

${ }^{2}$ Ordinates determined on the basis of bathymetric charts (IFI - Inland Fisheries Institute)

${ }^{3}$ Ordinates determined on the basis of measurement data (IMWM-NRI)

${ }^{4}$ Ordinates determined on the basis of our own research

b.d. - no data available 


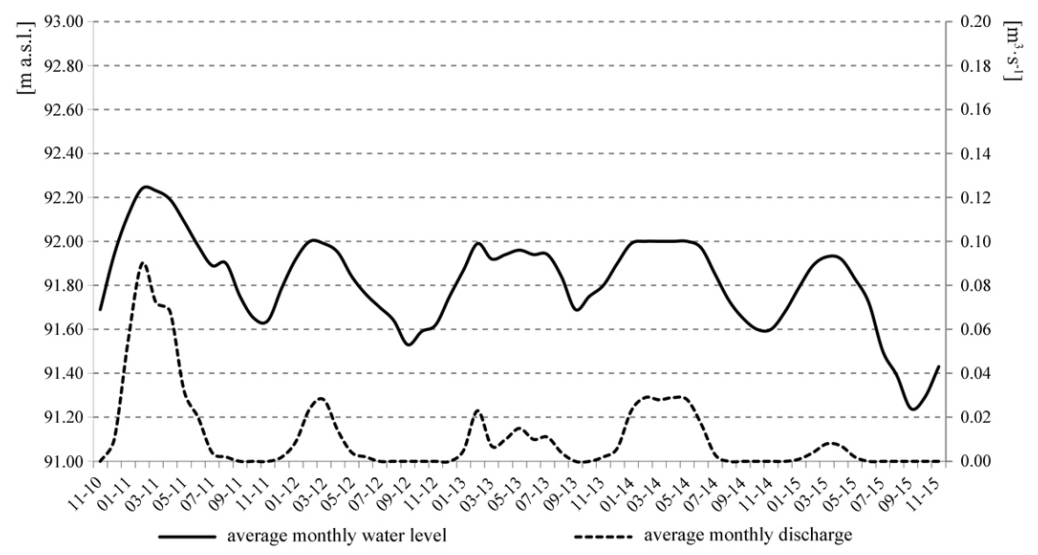

Fig. 6. Mean monthly water levels and mean monthly flows in Noteć Zachodnia in profile Słowikowo in 2011-2015 (after Nowak 2018a); regression line for water level: $y=-1.88^{*} 10^{\wedge}(-4) x+94.79$ - decreasing trend, statistically significant $(R=0.481, \alpha=0.001)$; regression line for discharge: $y=-1.435^{*} 10^{\wedge}(-5) x+0.24$ - decreasing trend, statistically significant $(R=0.411, \alpha=0.001)$

(Tab. 2) shows that the water level over the last 100 years in those particular lakes dropped by $0.6-1.4 \mathrm{~m}$ on average, representing the largest loss of water in the second half of the $20^{\text {th }}$ century. The sole exception is Lake Piłka, which was raised by over $3 \mathrm{~m}$ over the same time period to meet the needs of a small hydro-electric power station built at the lake outlet. The lowering of water level by the values given above over the last 100 years caused a decrease of water resources in the lakes by over 10 million $\mathrm{m}^{3}$, i.e. nearly $17 \%$ of their original capacity.

That phenomenon is a result of many different causes, including unfavorable climatic factors (Kędziora 2008, 2011; Stachowski et al. 2016; Nowak 2018a) and anthropogenic activities such as meliorations (Kaniecki 2011), mining drainage (Ilnicki 1996; Ilnicki, Orłowski 2006a, b; 2011; Orłowski, Ilnicki 2007; Przybyłek, Nowak 2011a), uptake ground waters (Przybyłek, Nowak 2011a; Nowak 2018a), or incorrect water management at the hydrotechnical structures situated on the rivers of the region. That last aspect is especially observable in relation to the river under study, on which five hydrotechnical structures were identified. Two of those structures are correctly operated and fulfil their functions. These are the two-gate sluice at Skorzęcin, situated below the outlet of Lake Niedzięgiel, and the three-gate sluice at Kamionek, located below the outlet of Lake Kamienieckie. Both have solid foundations and protection against water erosion. In each flow chamber, there are regulated gates with working drive systems. Below the Lakes Piłka and Słowikowo, structures remained after a former hydro-electric power station and a water mill were found. In both cases, the riverbed of Noteć Zachodnia is running in a several-kilometer long rectangular section concrete channel provided with metal guide-ways for adjustable positioning of elements damming the river. During the control geodetic and hydrometric measurements at those locations, the only means of damming water were unprotected wooden boards and gratings inserted in the guide-ways, thus preventing the migration of fish. In addition, at a distance of approximately $1 \mathrm{~km}$ below Lake Białe, the remains of a monk-type sluice were found on Noteć Zachodnia, which most likely had been used for water retention for firefighting purposes. At present, that structure has no moving elements, although it does have solid foundations and guide-ways in the flow chamber.

Knowing the natural ranges of water level fluctuations in the lakes (Tab. 2) and the technical parameters of the existing hydrotechnical structures, an attempt was made at determining the damming ordinates for all water bodies under study (Tab. 3). When determining the normal damming levels, the average water levels of the 1960s were used as supplementary information (Tab. 2 and 3). The maximum damming levels were determined on the basis of the average high water levels of that period (Tab. 2 and 3), keeping in mind the limitations resulting from the existing hydrotechnical infrastructure (Tab. 3) and the existing buildings in the shore zone of the lakes. In the case of Lake Skubarczewskie, which at present is not regulated, the location and preliminary concept of a hydrotechnical structure on its outlet were indicated in addition to the damming ordinates (Tab. 3).

According to the calculations, the greatest retention capacities were obtained in the case of the largest lakes, i.e. Lakes Skorzęcińskie and Kamienieckie. For the first of those, the retention capacity was $\sim 2.60 \cdot 10^{6} \mathrm{~m}^{3}$, and the flood capacity was $\sim 1.15 \cdot 10^{6} \mathrm{~m}^{3}$ (Fig. 7). For the second, those values were $\sim 1.42 \cdot 10^{6} \mathrm{~m}^{3}$ and $\sim 0.45 \cdot 10^{6} \mathrm{~m}^{3}$, respectively (Fig. 7). Overall, for the 6 lakes situated in the route of the Noteć Zachodnia River, those parameters were $3.46 \cdot 10^{6} \mathrm{~m}^{3}$ for the retention capacity and $1.76 \cdot 10^{6} \mathrm{~m}^{3}$ for the flood reserve (Fig. 7). These values indicate the retention potential for water flowing in the Noteć Zachodnia. On the other hand, they also reflect the amount of water 
resources lost from those lakes over the last 50 years.

The capacities indicated above allow not only the alimentation of waters in the lakes, but they can also, with suitable management of water discharge from the lakes, allow the control of flows in the river under study over the course of the year. This is particularly important in periods of high flows in the Noteć Zachodnia River, which may cause flooding in its lower reaches. In the year 2011, when extremely high water flows took place in the Noteć
Zachodnia (Fig. 5), the authors determined the potential for reducing the flood wave on that river with the use of the retention of the lakes situated in its course.

It was calculated that, using half of the retention capacity indicated above and the whole of the flood capacity of the water bodies under study, it would be possible to reduce the flood wave on the river by $30 \%$ for the profile closing the catchment basin below Lake Kamienieckie (Fig. 8). Especially during the first two months, when the flood wave

Table 3. Ordinates of characteristic water levels of studied lakes and existing and proposed damming ordinates for hydrotechnical structures situated in the route of the river Notec Zachodnia (on the basis of our measurements and data from Wielkopolski Board of Amelioration and Hydraulic Structures in Poznań)

\begin{tabular}{|l|c|c|c|c|c|c|c|c|c|c|}
\hline \multirow{2}{*}{ Object/Lake } & \multicolumn{3}{|c|}{ Lake ordinates [m a.s.1.] } & \multicolumn{4}{c|}{$\begin{array}{c}\text { Basic parameters of existing } \\
\text { hydrotechnical infrastructure } \\
\text { [m a.s.1. }\end{array}$} & \multicolumn{3}{c|}{$\begin{array}{c}\text { Proposed } \\
\text { damming ordinates } \\
\text { [m a.s.1.] }\end{array}$} \\
\cline { 2 - 14 } & $\begin{array}{c}\text { SSW } \\
(60 .)\end{array}$ & $\begin{array}{c}\text { SWW } \\
(60 .)\end{array}$ & $\begin{array}{c}\text { Summer } \\
2015\end{array}$ & $\begin{array}{c}\text { Barrage } \\
\text { ordinate }\end{array}$ & NPP & MaxPP & $\begin{array}{c}\text { Sluice } \\
\text { edge }\end{array}$ & $\begin{array}{c}\text { Weir } \\
\text { edge }\end{array}$ & NPP & MaxPP \\
\hline Skorzęcin/Lake Niedzięgiel & 103.60 & 104.00 & 103.12 & 103.30 & b.d & b.d. & 103.82 & 104.72 & 103.60 & 103.80 \\
\hline Las Białe/Lake Białe & 103.55 & 103.80 & 103.07 & 103.00 & none & none & none & 103.70 & 103.55 & 103.70 \\
\hline Piłka Młyn/Lake Piłka & 101.70 & 101.80 & 100.81 & 100.90 & none & none & $\begin{array}{c}\text { wooden } \\
\text { boards }\end{array}$ & 101.80 & 101.70 & 101.80 \\
\hline Kinno/Lake Skubarczewskie & 93.00 & 93.20 & 92.42 & none & none & none & none & none & 93.00 & 93.15 \\
\hline Słowikowo/Lake Słowikowo & 92.50 & 93.00 & 91.30 & 91.35 & $92.00^{*}$ & $92.20^{*}$ & $\begin{array}{c}\text { wooden } \\
\text { boards }\end{array}$ & 92.60 & 92.30 & 92.60 \\
\hline Kamionek/Lake Kamienieckie & 84.90 & 85.60 & 84.48 & 84.00 & $84.31^{*}$ & $84.56^{*}$ & $84.59^{*}$ & $85.49^{*}$ & 84.80 & 85.00 \\
\hline
\end{tabular}

SSW - medium water; SWW - medium high water; NPP - normal damming level; MaxPP - maximum damming level; * - data from Wielkopolski Board of Amelioration and Hydraulic Structures in Poznań
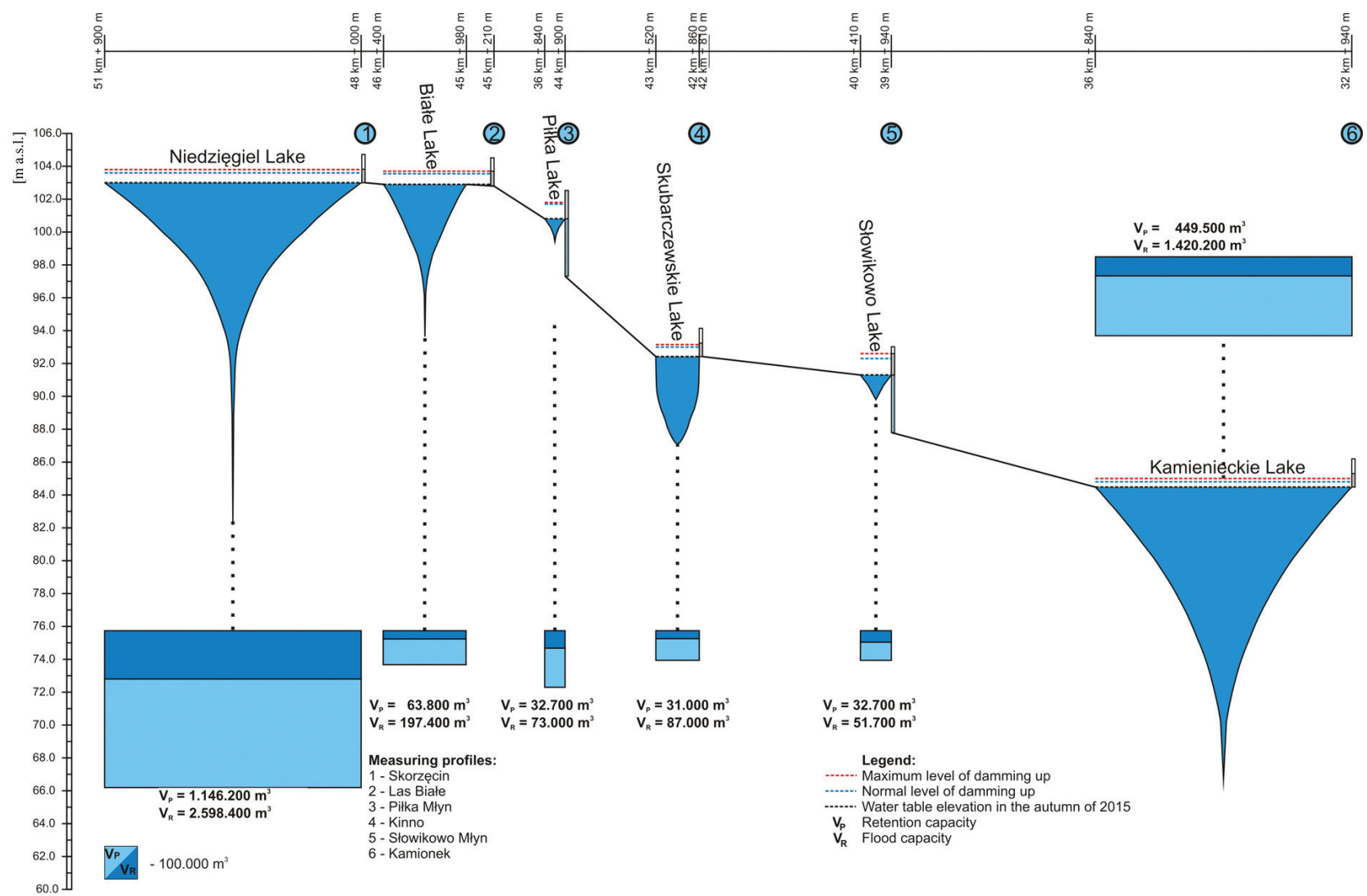

Fig. 7. Retention capacities of lakes in the studied area 


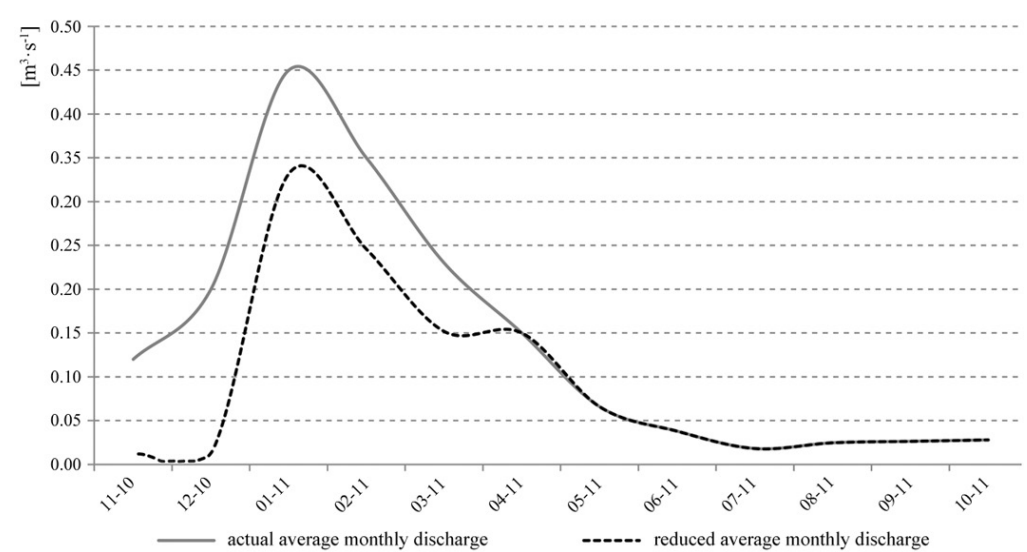

Fig. 8. Flow hydrograph for the river Noteć Zachodnia in profile Kamionek under actual conditions and with reduced flow as a result of use of the flood reservoirs of the studied lakes

started forming, it was possible to significantly reduce the flow in the river, as the analyzed lakes had a large margin of free capacity. In the case of Lake Niedzięgiel and Lake Białe, it was possible to wholly intercept the water carried by the tributaries of those lakes and originating from surface runoff. On the other lakes, those possibilities are considerably lower due to the expansion of the catchment basin and the existing melioration network, which accelerates the runoff of precipitation and thaw waters. However, the retention of waters carried by the Noteć Zachodnia River in those lakes would be large enough to still have a significant effect on the improvement of flood protection in the lower sections of the river.

\section{Discussion and conclusions}

Analysis of the available hydrological data and archival topographic maps reveals that a significant loss of water is observed in the region under study. This is expressed primarily by the distinct decreasing trends in water flows observed in the main rivers, the source zones of which are situated in this part of Poland (Tomaszewski 2007; Wrzesiński 2009; Nowak 2018a), and by the lowering of the water levels in the lakes (Ilnicki 1996; Ilnicki, Orłowski 2006a; Orłowski, Ilnicki 2007; Choiński, Ptak 2008; Kędziora 2008; Kowalik et al. 2008; Marszelewski, Radomski 2008; Kunz et al. 2010; Marszelewski et al. 2011; Ptak, Ławniczak 2011; Ilnicki et al. 2012a, b; Nowak, Gezella-Nowak 2012; Piasecki, Marszelewski 2013; Piasecki, Skowron 2014; Stachowski et al. 2016; Nowak 2018a) and ground water levels (Przybyłek, Nowak 2011a, b; Nowak 2018a). The lowering of the level of surface and ground waters in the study region is also related to climate factors (Kędziora 2008; Przybyłek, Nowak 2011a; Ilnicki et al. 2012a, b; Stachowski et al. 2016; Nowak 2018a), such as the increase in air temperature observed for many years (Kundzewicz, Matczak 2012; Twardosz, Kossowska-Cezak 2013; Graczyk, Kundzewicz 2014; Graczyk et al. 2016; Wibig 2018). Equally important is human activity, such as the meliorations realized in this part of Poland on a large scale since the middle of the $19^{\text {th }}$ century (Choiński, Ptak 2008; Marszelewski et al. 2011; Ptak, Ławniczak 2011; Ilnicki et al. 2012a, b) or the excessive uptake of waters for municipal and agricultural purposes (Przybyłek, Nowak 2011a; Nowak 2018a) and mining drainage conducted for several dozen years at the group of lignite opencast mines situated at a distance of 30-40 $\mathrm{km}$ from the study area (Kaniecki 1991; Rotnicka 1991; Sawicki 2000; Przybyłek, Nowak 2011a, b; Nowak, Gezella-Nowak 2012; Nowak 2018a).

An easy to realize and economically viable method of reversing those negative phenomena in the studied catchment basin is to raise the water level in the lakes situated in the route of the Noteć Zachodnia River. Importantly, in most of the indicated lakes, those activities would not require the creation of new hydrotechnical structures, but they would be limited to their overhaul. The damming ordinates indicated for the projected weirs would also not go beyond the natural oscillation of water levels in those lakes. Such an operation would allow the restoration of lost water resources and their better management in the future. Similar conclusions are presented by Sojka et al. (2010) for water bodies situated in the catchment basin of Struga Dormowska, by Ptak (2014) for selected lakes of the Wielkopolskie and Pomorskie Lakelands, and by Ptak and Małecki (2014) for Lake Włókno situated in the north Wielkopolska region. As can be seen from experience with other lakes situated in west and central Poland, damming waters in lakes not only prevents the loss of water resources in a water body itself and in its catchment basin, but it also allows the flow to be stabilised in the river that drains the dammed lake (Nowak, Grześkowiak 2010; Nowak et al. 2011b; Grześkowiak et al. 2012; Nowak, Ptak 2018a). 
The sense of damming lakes and the benefits thereof are emphasized by Jańczak et al. (2004), who indicated the retention possibilities of selected lakes in Poland, and by Nowak and Ptak (2018b), who pointed out the high potential for water retention in the lakes of the region of Wielkopolska. Lake damming is also successfully used in the realization of the Small Retention Program, especially by the former Provincial Boards of Amelioration and Hydraulic Structures and by the National Forests.

In the case of the lakes under study, the effect of restoration of their water resources will be possible to achieve through the use and modernization of the existing hydrotechnical infrastructure and the construction of new objects at several suitable locations. Taking into account the parameters of the hydrotechnical objects and realistic possibilities of lake damming, and without exceeding the natural ranges of water level fluctuations, we suggest the following solutions for specific lakes in the route of the Noteć Zachodnia River:

- Lake Niedzięgiel - creation of a manual of water management on the existing object on the basis of determined damming ordinates;

- Lake Białe - renovation of the existing monk-type sluice at the outlet of the lake;

- Lake Piłka - installation of a permanent barrier in the channel of the former mill sluice;

- Lake Skubarczewskie - construction of a two-gate sluice above the road culvert $100 \mathrm{~m}$ below the lake;

- Lake Słowikowo - construction of a two-gate sluice at the site of the former mill sluice and construction of a damming weir on the relief canal at an ordinate equal to NPP;

- Lake Kamienieckie - increase of the height of the barriers and creation of a water management manual based on the determined damming ordinates.

Implementation of these solutions will allow correct water relations to be maintained in the catchment basin, and it will reduce the potential for unfavorable extreme water levels of the lake, that have a negative effect on the functioning of aquatic ecosystems. Hydrotechnical structures situated on the lakes will allow storing water surplus in periods of thaw and will reduce water outflow in periods of summer-autumn low water levels. Thanks to this, it will be possible to have water in the river bed throughout the year, which will be a beneficial natural effect (Nowak, Ptak 2018a). Water retained in the lakes will ensure greater living space for animals inhabiting aquatic systems, especially fish. A long-term indirect effect of stabilization of water level in the lakes situated in the route of the Noteć Zachodnia River will be the raising of ground water levels in areas adjacent to the dammed lakes, an increase of soil retention, and restoration of degraded wetlands (Nowak, Ptak 2018a). Water stored in this manner will become easily available for plants in dry periods. A measurable effect of maintaining higher water levels in the lakes and in the river will also include the possibility of better water supply for fish ponds, and securing water supply for firefighting and potentially for irrigation.

On the other hand, correct management of the hydrotechnical structures mentioned above and control of water outflow at outlets from the lakes under discussion may contribute to a reduction of flood wave on the Noteć Zachodnia River. This would augment the operation of the Pakoski Reservoir and the system of weirs situated in the central section of the Noteć River, in the valley of which there were numerous flooding events in 2011.

An investment consisting of the raising of water levels in lakes situated in the route of the Noteć Zachodnia River, apart from the target positive natural and economic effects on the local scale, will also fit in with numerous projects of priority character for the region of Wielkopolska. This would serve to improve the state of the environment and increase the economic and tourism potential of rural areas (Wielkopolski Regional Operational Program for the years 2014-2020, Development Strategy of the Province of Wielkopolska until the year 2020, Small Retention Program for the Province of Wielkopolska). Such activities will also be in conformance with the national programs aimed at improving the quality of waters and optimization of the use of water resources (National Water-Environmental Program, Draft of Water Policy Project of the Country till the year 2030, Plan of Water Management in the Catchment Basin of River Odra 2030, Program of Conservation of Lakes of North Poland) as well as enhancing the attractiveness of areas related to aquatic ecosystems (Program of Rural Areas Development, Operation Program Infrastructure and the Environment 2014-2020).

\section{Acknowledgements}

This research was co-financed from funds of research project DS-H 5/2017 Evaluation of the possibilities to use lakes in flood protection and restoring water resources in the upper and middle Noteć River catchment, realized within the framework of the statutory activity of IMWM-NRI and the National Science Centre research project for young scientists entering education, without doctoral degree - PRELUDIUM entitled Lakes in circulation and drainage of groundwater in the area of the last glacial period in natural conditions and conditions of hydrodynamic pressure (UMO-2011/03/N/ ST10/05014), implemented in 2012-2015 
Bibliography

Choiński A., Ptak M., 2008, The Wielkopolska lakes shrinkage against the background of Poland, (in Polish), Roczniki Gleboznawcze, 54 (2), 25-31

Choiński A., Ptak M., Ławniczak A.E., 2016, Changes in water resources of Polish lakes as influenced by natural and anthropogenic factors, Polish Journal of Environmental Studies, 25 (5), 1883-1890, DOI: 10.15244/pjoes/62906

Choiński A., Ptak M., Strzelczak A., 2012, Examples of lake disappearance as an effect of reclamation works in Poland, Limnological Review, 12 (4), 161-167, DOI: 10.2478/v10194012-0056-2

Cupak A., 2012, Determination of low-flows in uncontrolled catchments using the regionalization, (in Polish), Gaz, Woda i Technika Sanitarna, 2, 62-64

Farat R. (ed.), 2004, Climate atlas of the Wielkopolskie voivodship, (in Polish), IMGW, Poznań, 139 pp.

Graczyk D., Kundzewicz Z.W., 2014, Changes in thermal extremes in Poland, Acta Geophysica, 62 (6), 1435-1449, DOI: $10.2478 / \mathrm{s} 11600-014-0240-7$

Graczyk D., Pińskwar I., Kundzewicz Z.W., Øystein H., Førland E.J., Szwed M., Choryński A., 2016, The heat goes on changes in indices of hot extreme in Poland, Theoretical and Applied Climatology, 129 (1-2), 459-471, DOI: 10.1007/ s00704-016-1786-x

Graf R., 2010, Tendencies in the changes of shallow groundwater levels in the Wielkopolska Lowland in the years 1961-2000), [in:] Resources, threats and protection of groundwater, R. Graf, M. Marciniak (eds.), Seria Studia i Prace z Geografii i Geologii, 11, 79-95

Grześkowiak A., Nowak B., Nowak D., 2012, The possibility of water retention of the Lednica Lake and its catchment, (in Polish), Biuletyn Parków Krajobrazowych Wielkopolski, 18 (20), 119-130

Ilnicki P., 1996, Impact of the lignite opencast drainage on the recreational values at the Gniezno Lakeland, (in Polish), Aura, 11, 10-12

Ilnicki P., Farat R., Górecki K., Lewandowski P., 2012a, Great Poland is not stepping, (in Polish), Wiadomości Melioracyjne i Łąkarskie, 4, 152-158

Ilnicki P., Farat R., Górecki K., Lewandowski P., 2012b, The myth of stepping Great Poland in the light of the long-term water cycle research, (in Polish), Wydawnictwo Naukowe Uniwersytetu Przyrodniczego w Poznaniu, Poznań, 398 pp

Ilnicki P., Górecki K., Szczepański M., 2017, Accelerated peatland disappearance in the vicinity of the Konin brown coal strip mine, Journal of Water and Land Development, 35, 89-93

Ilnicki P., Orłowski W., 2006a, Evaluation of the impact of drainage in the Kleczew region conducted by the Brown
Coal Mine "Konin" S.A. in Kleczew to the water levels in the lakes located on the watershead of the Noteć River and the Warta River, (in Polish), Polskie Towarzystwo Rybackie, Poznań, 201 pp.

Ilnicki P., Orłowski W., 2006b, Ecological disaster in the Powidzki Landscape Park, (in Polish), Aura, 10, 11-14

Ilnicki P., Orłowski W., 2011, Resignation from retention of water in the watershead of Noteć River and Warta River is contrary to the principle of sustainable development, (in Polish), Gospodarka Wodna, 8, 322-328

Jańczak J., Kowalik A., Brodzińska B., 2004, Theoretical possibilities of retention capacity of larger Polish lakes, (in Polish), Zeszyty Naukowe Akademii Rolniczej we Wrocławiu, 502, Inżynieria Środowiska, 13, 125-132

Jańczak J., Kowalik A., Sziwa R., 2001, The influence of lake damming on the flow of the Noteć Zachodnia River and the quality of water in the Pakoskie Lakes, (in Polish), [in:] Dynamika obiegu wody w zlewniach rzecznych, J. Jaworski, J. Szkutnicki (eds.), IMGW, Warszawa, 137-143

Kaniecki A., 1991, Changes in the water conditions of the Konin region generated by opencast mining, (in Polish), [in:] Przemiany środowiska geograficznego obszaru KoninTurek, W. Stankowski (ed.), Wydawnictwo Naukowe UAM, Poznań, 137-151

Kaniecki A., 2011, Changes in water relations in the upper Noteć River valley up to the mid- $19^{\text {th }}$ century related to anthropopressure, (in Polish), Badania Fizjograficzne A, 62, 41-58

Kędziora A., 2008, Water balance of Konin strip mine landscape in changing climatic conditions, (in Polish), Roczniki Gleboznawcze, 59 (2), 104-118

Kędziora A., 2011, Climatic conditions and water balance of the Kujawy Lakeland, (in Polish), Roczniki Gleboznawcze, 62 (2), 189-203

Kondracki J., 2009, Regional geography of Poland, (in Polish), Wydawnictwo Naukowe PWN, Warszawa, 441 pp.

Kowalik A., Grześkowiak A., Nowak B., 2008, Lakes' reaction to extreme changes in their supply, (in Polish), Wiadomości Meteorologii Hydrologii i Gospodarki Wodnej, 52 (3-4), 49-68

Kundzewicz Z.W., Matczak P., 2012, Climate change regional review: Poland, WIREs Climate Change, 3, 297-311, DOI: $10.1002 /$ wcc. 175

Kunz M., Skowron R., Skowroński S., 2010, Morphometry changes of Lake Ostrowskie (the Gniezno Lakeland) on the basis of cartographic, remote sensing and geodetic surveying, Limnological Review, 10 (2), 77-85, DOI: 10.2478/ v10194-011-0009-1

KZGW, 2011a, Draft of Water Policy Project of the Country till the year 2030, (in Polish), available at https://mdwe70. pl/documents/1237983/1240047/img/e2f3addf-f600-4b70820 c-f58efeef683b (data access 27.04.2018) 
KZGW, 2011b, Plan of Water Management in the Catchment Basin of River Odra, (in Polish), available at http://prawo. sejm.gov.p1/isap.nsf/download.xsp/WMP20110400451/O/ M20110451.pdf (data access 08.05.2018).

KZGW, 2016, National Water Environmental Program, (in Polish), available at http://www.kzgw.gov.pl/images/Aktualnosci/20161012/aPWSK.pdf (data access 27.04.2018)

Ławniczak A.E., 2010, Overgrowing of two polymictic lakes in Central-Western Poland, Limnological Review, 10 (3-4), 147-156, DOI: 10.2478/v10194-011-0017-1

Ławniczak A.E., Choiński A., Kurzyca I., 2011, Dynamics of lake morphometry and bathymetry in various hydrological conditions, Polish Journal of Environmental Studies, 20 (4), 931-940

Ławniczak A.E., Kutyła S., 2015, Lake-area changes in selected protected areas on the basis of cartographic materials, Przegląd Geograficzny, 87 (1), 95-107

Mączkowski K., 2013, Program of Conservation of Lakes of North Poland, (in Polish), available at http://www. archiwum3.wolsztyn.pl/zdjecia/strona/wiadomosci/konferencja/13092013/prezentacje/9.pdf (data access 08.05.2018)

Marszelewski W., Ptak M., Skowron R., 2011, Anthropogenic and natural conditionings of disappearing lakes in the Wielkopolska-Kujawy Lake District, (in Polish), Roczniki Glebozawcze, 62 (2), 283-294

Marszelewski W., Radomski B., 2008, Quantitative degradation of water resources of the lakes in the eastern part of the Gniezno Lakeland, [in:] Anthropogenic and natural transformations of lakes, vol. 2, E. Bajkiewicz-Grabowska, D. Borowiak (eds.), Polskie Towarzystwo Limnologiczne, Gdańsk, 119-122

MIR, 2014, Operation Program Infrastructure and Environment 2014-2020, (in Polish), available at https://www.pois.gov.pl/ media/1238/POIS_2014_2020_13022015.pdf (data access 08.05.2018)

MRiRW, 2017, Program of Rural Areas Development, (in Polish), available at http://www.minrol.gov.pl/Wsparcie-rolnictwa/ Program-Rozwoju-Obszarow-Wiejskich-2014-2020 (data access 08.05.2018)

Nowak B., 2018a, The role of lakes in drainage and recharge of groundwater in the Gniezno Lakeland area in natural conditions and conditions of hydrodynamic anthropopressure, (in Polish), Ph.D. dissertation, Adam Mickiewicz University in Poznań, 198 pp.

Nowak B. (ed.), 2018b, Report on the implementation of research topic DS-H 5/2017 titled Evaluation of the possibilities to use lakes in flood protection and restoring water resources in the upper and middle Noteć River catchment, (in Polish), IMGW-PIB, Poznań, 28 pp.

Nowak B., Brodzińska B., Gezella-Nowak I., 2011a, Natural and economic factors of shrinkage of lakes of the Wielkopol- ska Lakeland, Limnological Review, 11 (3), 123-132, DOI: 10.2478/v10194-011-0034-0

Nowak B., Gezella-Nowak I., 2012, Causes of severe lowflows events of Powidzkie Lake (Gniezno Lakeland), [in:] Conference materials of International Limnological Conference "Natural and anthropogenic transformations of lakes", Łagów Lubuski, 19-21.09.2012, A. Grześkowiak, B. Nowak (eds.), IMGW-PIB, Poznań,71-72

Nowak B., Grześkowiak A., 2010, Assessment of impact of lake damming as the preliminary element of revitalization model of Wielkopolska Region Lakes, (in Polish), [in:] Zarządzanie zasobami wodnymi w dorzeczu Odry, B. Mońka (ed.), Wydawnictwo PZITS, Wrocław, 271-280

Nowak B., Nowak D., Grześkowiak A., Kornaś M., Żak J., 2011b, Charakteristics of the Lednica Lake and its catchment taking into account the threats to its water and the proposed protective action, (in Polish), IMGW-PIB, Poznań, 76 pp.

Nowak B., Przybyłek J., 2008, Groundwater level oscillation in the Poznańskie Lake District during the last three decades and its impact on lakes on the example of Góreckie Lake, [in:] Anthropogenic and natural transformations of lakes, vol. 2, E. Bajkiewicz-Grabowska, D. Borowiak (ed.), Polskie Towarzystwo Limnologiczne, Gdańsk, 135-137

Nowak B., Ptak M., 2018a, Effect of a water dam on Lake Powidzkie and its vicinity, Bulletin of Geography. Physical Geography Series, 15, 5-13, DOI: 10.2478/bgeo-2018-0011

Nowak B., Ptak M., 2018b, Potential use of lakes as a component of small retention in Wielkopolska, Conference Materials of Conference EKO-DOK 2018, Polanica-Zdrój, 16-18 April 2018, (in press)

Orłowski W., Ilnicki P., 2007, Problems of water management in the surroundings of the Brown Coal Mine Konin, (in Polish), Gospodarka Wodna, 9, 383-386

Piasecki A., Marszelewski W., 2013, Short-term changes in water resources of lakes in the Ostrowo-Gopło Canal catchment, (in Polish), Wydawnictwo Bezkresy Wiedzy, Saarbrücken, 112 pp.

Piasecki A., Skowron R., 2014, Changing the geometry of basins and water resources of Lakes Gopło and Ostrowskie under the influence of anthropopressure, Limnological Review, 14 (1), 33-43, DOI: 10.2478/limre-2014-0004

Przybyłek J., Nowak B., 2011a, Impact of hydrogeological low flows and groundwater drainage by lignite open cast mine on aquifer systems in Gniezno Lakeland, (in Polish), Biuletyn PIG, 445, Seria Hydrogeologia, 12/2, 513-527

Przybyłek J., Nowak B. (eds.), 2011b, Hydrogeological and natural problems associated with the exploitation of lignite in Wielkopolska Region - A guidebook to the field session no. II organized as part of the XV Symposium „Współczesne Problemy Hydrogeologii”, Poznań -Zerków, 14-16.09.2011, (in Polish), Poznań, 50 pp. 
Ptak M., 2013, Lake evolution in the Żnin region in the years 1912-1960 (central Poland), Quaestiones Geographicae, 32 (1), 21-26

Ptak M., 2014, Feasibility of increasing water resources of Poland by restoration of extinct lakes - selected examples, (in Polish), Słupskie Prace Geograficzne, 11, 5-14

Ptak M., Choiński A., Strzelczak A., Targosz A., 2013, Disappearance of Lake Jelenino since the end of the XVIII century as an effect of anthropogenic transformations of the natural environment, Polish Journal of Environmental Studies, 22 (1), 191-196

Ptak M., Ławniczak A., 2011, Changes in water resources in selected lakes in the middle and lower catchment of the River Warta, Limnological Review, 11 (1), 25-32, DOI: 10.2478/ v10194-011-0024-2

Ptak M., Małecki J.Z., 2014, A theoretical assessment of the possibility to increase the water retention based on example Włókna Lake, (in Polish), Zeszyty Naukowe - Inżynieria Lądowa i Wodna w Kształtowaniu Środowiska, 10, 19-25

Rotnicka J., 1991, Changes in the surface and ground water balance in the Konin brown-coal mining area, [in:] Przemiany środowiska geograficznego obszaru Konin-Turek, W. Stankowski (ed.), Wydawnictwo Naukowe UAM, Poznań, 153-163

Sawicki J., 2000, The changes of natural infiltration of precipitation into aquifers the result of deep mining groundwater drainage, (in Polish), Oficyna Wydawnicza Politechniki Wrocławskiej, Wrocław, 174 pp.

Sojka M., Jaskuła J., Wicher-Dysarz J., Dysarz T., 2017, Analysis of selected reservoirs functioning in the Wielkopolska region, Acta Scientiarum Polonorum, Formatio Circumiectus, 16 (4), 205-215, DOI: 10.15576/ASP.FC/2017.16.4.205

Sojka M., Murat-Błażejewska S., Kanclerz J., 2010, Assessment of water retention possibilities in the catchment of the Struga Dormowska River, (in Polish), Infrastruktura i Ekologia Terenów Wiejskich, 8 (1), 5-13

Skowron R., Jaworski T., 2017, Changes in lake area as a consequence of plant overgrowth in the South Baltic Lakelands (Northern Poland), Bulletin of Geography. Physical Geography Series, 12, 19-30, DOI: 10.2478/11383
Stachowski P., Oliskiewicz-Krzywicka A., Kupiec J.M., 2016, The natural characteristics of the state of the water in lakes in the area of open mine quarry "Konin”, (in Polish), Rocznik Ochrona Środowiska, 18 (1), 642-669

Tomaszewski E., 2007, Selected parameters of the low flow structure on the study case of the central Poland rivers, (in Polish), [in:] Obieg wody w środowisku naturalnym i przekształconym, Z. Michalczyk (ed.), Wydawnictwo UMCS, Lublin, 548-556

Twardosz R., Kossowska-Cezak U., 2013, Exceptionally hot summers in Central and Eastern Europe (1951-2010), Theoretical and Applied Climatology, 112 (3-4), 617-628, DOI: 10.1007/s00704-012-0757-0

Urbański J., 2008, GIS in natural research, (in Polish), Wydawnictwo UG, Gdańsk, 266 pp.

WFOŚiGW, 2015, Small Water Retention Program for the Province of Wielkopolska for the years 2016-2030, (in Polish), available at http://wzmiuw.pl/tekstowe/program-malej-retencji-wfosigw_8e42259.pdf (data access 08.05.2018)

Wibig J., 2018, Heat waves in Poland in the period 1951-2015: trends, patterns and driving factors, Meteorology Hydrology and Water Management, 6 (1), 1-9, DOI: 10.26491/ mhwm/78420

Wokroj J., 1967, Application of analogy in hydrological calculations, (in Polish), Gospodarka Wodna, 6, 209-212

Wrzesiński D., 2009, Tendencies of change in the flow of rivers in Poland in the second half of the 20th century, (in Polish), Badania Fizjograficzne nad Polską Zachodnią, 60, 147-162

Zarząd Województwa Wielkopolskiego, 2012, Development Strategy of the Province of Wielkopolska until the year 2020, (in Polish), available at http://www.wrpo2007-2013. wielkopolskie.p1/zalaczniki1/2013/Zaktualizowana_Strategia_RWW_do_2020.pdf (data access 27.04.2018)

Zarząd Województwa Wielkopolskiego, 2014, Wielkopolski Regional Operational Program for the years 2014-2020, (in Polish), available at http://wrpo.wielkopolskie.pl/system/file_resources/attachments/000/000/438/ original/WRPO_2014_wersja_zatwierdzona_przez KE.pdf?1431498290 (data access 08.05.2018) 